\title{
Lovastatin, but not orlistat, reduces intestinal polyp volume in an $\mathrm{Apc}^{\mathrm{Min} / \mathrm{+}}$ mouse model
}

\author{
MARIA NOTARNICOLA $^{1 *}$, MICHELE BARONE $^{3 *}$, ANTONIO FRANCAVILLA $^{3}$, VALERIA TUTINO $^{1}$, \\ GIUSY BIANCO $^{2}$, ANGELA TAFARO ${ }^{2}$, MARIO MINOIA $^{2}$, LORENZO POLIMENO ${ }^{3}$, ANNA NAPOLI $^{4}$, \\ MARIA PRINCIPIA SCAVO ${ }^{3}$ and MARIA GABRIELLA CARUSO ${ }^{1}$ \\ ${ }^{1}$ Laboratory of Nutritional Biochemistry and ${ }^{2}$ Animal Facility, National Institute for Digestive Diseases 'S. de Bellis', \\ Castellana Grotte, Bari; ${ }^{3}$ Gastroenterology and ${ }^{4}$ Pathology Unit, Department of Emergency \\ and Organ Transplantation, University of Bari, Bari, Italy
}

Received December 15, 2015; Accepted January 21, 2016

DOI: 10.3892/or.2016.4856

\begin{abstract}
The statins, inhibitors of 3-hydroxy-3-methylglutaryl coenzyme A reductase (HMGCoAR) and orlistat, an inhibitor of fatty acid synthase (FAS), inhibit tumor cell growth by restricting cholesterol and fatty acid synthesis, respectively. We previously demonstrated that an omega $(\omega)-3$ polyunsaturated fatty acid (PUFA)- or olive oil-enriched diet reduced the polyp number and volume in $\mathrm{Apc}^{\mathrm{Min} /+}$ mice. This phenomenon was associated with a significant inhibition of FAS and HMGCoAR, as well as an increase in the estrogen receptor (ER) $\beta / \alpha$ ratio. Herein, we evaluated the effect of lovastatin and orlistat on polyp development and ER expression in $\mathrm{Apc}^{\mathrm{Min} /+}$ mice, in order to confirm previous data obtained with $\omega$-3-PUFAs and olive oil. As expected, the use of lovastatin and orlistat significantly reduced HMGCoAR and FAS enzymatic activities and gene expression in colonic tissues, but did not affect the number of intestinal polyps, while there was a statistically significant reduction in polyp volume only in the mouse group treated with lovastatin. In the mice receiving orlistat, we observed a significant increase in cell proliferation in the polyp tissue, as well as enhanced expression of ER $\alpha$. Moreover, the overexpression of $\mathrm{ER} \alpha$ was associated with a statistically significant increase in PES1, Shh and Gli1 protein levels, considered ER $\alpha$-related molecular targets.
\end{abstract}

\section{Introduction}

The inhibitors of 3-hydroxy-3-methyl-glutaryl-coenzyme A reductase (HMGCoAR) and fatty acid synthase (FAS) enzymes are known to have selective cytotoxic activity against

Correspondence to: Dr Maria Gabriella Caruso, Laboratory of Nutritional Biochemistry, National Institute for Digestive Diseases, Via Turi 27, I-70013 Castellana Grotte, Bari, Italy

E-mail: gabriella.caruso@irccsdebellis.it

*Contributed equally

Key words: lipogenic enzymes, orlistat, lovastatin, colon cancer, estrogen receptor cancer cells both in vitro and in various in vivo models (1-3). Several studies have demonstrated that statins, inhibitors of HMGCoAR, and orlistat, an inhibitor of FAS, inhibit tumor cell growth by restricting cholesterol and fatty acid synthesis, respectively (4-8).

Previously, we demonstrated in an HepG2 cell line (9) a synergistic effect in the inhibition of cancer cell proliferation obtained by combination of eicosapentaenoic acid (EPA, an omega ( $\omega)$-3-polyunsaturated fatty acid) and lovastatin, demonstrating an inhibition at the lower doses with respect to the substances used separately.

In an in vivo model of colon carcinogenesis, $\mathrm{Apc}^{\mathrm{Min} /+}$ mice, we previously demonstrated that natural compounds such as olive oil and $\omega-3$-polyunsaturated fatty acids ( $\omega$-3-PUFAs), when administered to mice that spontaneously develop intestinal polyps, were able to reduce the polyp number and volume by decreasing proliferation and increasing pro-apoptotic activity (10). These biological effects were associated with inhibition of HMGCoAR and FAS gene expression and activity and with an increase in the ratio of estrogen receptor $\beta /$ estrogen receptor $\alpha(\mathrm{ER} \beta / \mathrm{ER} \alpha$ ratio).

Estrogens and relative receptors are involved in the aetiology and/or progression of many types of cancers, including colon cancer (11). ER $\beta$ is abundantly expressed in the normal colon but shows progressively decreased expression in human adenomatous sporadic polyps (11) and in $\mathrm{Apc}^{\mathrm{Min} /+}$ mice (10). Downregulation of ER $\beta$ expression has also been detected in individuals with familial adenomatous polyposis and colorectal cancer, and was found to be correlated with disease progression and aggressiveness (12-15).

In contrast, ER $\alpha$ is a well-known mediator of cell proliferation activity $(16,17)$; it acts by enhancing the transcription of factors associated with cell proliferation and shows an increased expression in colon cancer as compared to normal surrounding tissue (17). In particular, ER $\alpha$ protein expression has been demonstrated to play a role in the regulation of the hedgehog (Hh) signaling pathway which, in turn, regulates proliferation, angiogenesis, matrix remodeling and stem-cell renewal (18). Alterations of the $\mathrm{Hh}$ pathway have been found in patients with various types of cancers including colorectal cancer (19). Moreover, in gastric cancer a biologically significant linkage 
has been shown between the ER $\alpha$ and Hh pathways; estrogens activate the ER $\alpha$ pathway, which induces sonic hedgehog (Shh) production, responsible for the activation of Hh that increases cell proliferation (20). Finally, activation of the Hh pathway induces an overexpression of Glil, the glioma-associated oncogene homolog family of transcription factors, that is known to play a role in tumorigenesis (21). Recently, dysregulated expression of PES1, an estrogen-inducible protein also known as Pescadillo, was found to be associated with cancer development (22-24); PES1 seems to exert differential actions on the transcriptional responses of the ER subtypes in breast cancer, increasing the transcriptional activity of ER $\alpha$ and decreasing that of $\operatorname{ER} \beta$ (25).

On the basis of this experimental evidence, in the present study, we evaluated whether lovastatin and orlistat exert effects on polyp formation in $\mathrm{Apc}^{\mathrm{Min} /+}$ mice similar to the effects obtained with the use of natural compounds, such as olive oil and $\omega$-3-PUFAs. In addition, since preliminary results using these drugs indicated a decrease in ER $\beta$ associated with an increase in $\mathrm{ER} \alpha$, we focused our attention on $\mathrm{ER} \alpha$ and its related molecular targets, PES1, Shh and Gli1.

\section{Materials and methods}

Animals and experimental study design. Five-week-old $\mathrm{C} 57 \mathrm{BL} / 6 \mathrm{~J}$ male mice with a heterozygote mutation for the $A p c$ gene $\left(A p c^{M i n /+}\right)$ were obtained from Charles River Laboratories Italia (Calco, LC, Italy). Mice were maintained under temperature-, air- and light-controlled conditions and received food and water ad libitum; they did not receive any surgical or hormonal manipulation. All animals received care in compliance with the Guide for the Care and Use of Laboratory Animals by the Italian Ministry of Health. The procedures related to animal use were communicated to and approved by the Italian Ministry of Health.

The $\mathrm{Apc}^{\mathrm{Min} / \mathrm{t}}$ mice were randomly divided into 3 groups of 10 animal each and fed for 10 weeks as follows: control (ST) group, that received a standard diet (12.5\% protein, $12 \%$ soybean oil, $3 \%$ fiber); lovastatin (LOVA) group, that received a standard diet supplemented with lovastatin $(20 \mathrm{mg} / \mathrm{kg})$; orlistat (OR) group, that received a standard diet supplemented with orlistat $(200 \mathrm{mg} / \mathrm{kg})$. All diets were isocaloric and supplied as pellets (Mucedola Srl, Settimo Milanese, Italy). Mouse body weight and food intake were measured every 3 days.

After 10 weeks of dietary treatment, all animals were sacrificed by cervical dislocation and the entire intestinal tract was immediately removed and washed with cold phosphate-buffered saline (PBS).

In the $\mathrm{Apc}^{\mathrm{Min} /+}$ mice, the volume of polyps was calculated considering polyps as hemispheres $\left(1 / 2 \times 3 / 4 \pi r^{3}\right)$. The small intestine and colon were cut along the mesenteric insertion, placed on a paper strip at $0^{\circ} \mathrm{C}$ to $4^{\circ} \mathrm{C}$ and analyzed through a stereomicroscope at $\mathrm{x} 3$ magnification by two independent observers. For our evaluations, the small intestine was further divided into proximal, medial and distal segments. One portion of the intestinal segments of all animals was immediately put into RNAlater ${ }^{\circledR}$ and stored at $-20^{\circ} \mathrm{C}$, and another portion was placed in liquid nitrogen in order to run real-time PCR and western blot analyses, respectively. The remaining portion of the intestinal segments was fixed in $10 \%$ neutral buffered formalin for $24 \mathrm{~h}$ and embedded in paraffin in a 'Swiss roll' fashion. Paraffin-embedded tissues were processed for light and confocal microscopy studies.

Histological studies. To evaluate the grade of dysplasia, hematoxylin and eosin-stained sections were examined in a blinded fashion by two pathologists. Dysplasia was defined as the occurrence of disorganized glandular architecture, depletion of mucin-producing cells and goblet cells, nuclear atypia and increased mitotic activity, and was graded mild, moderate or severe as previously described (12). The further presence of tissue hypercellularity, enhanced cell polymorphism and degenerative/necrotic phenomena allowed us to recognize cancerous lesions.

Proliferating cell nuclear antigen (PCNA) assay. Cell proliferation was evaluated by PCNA assay. Distal tissue sections underwent antigen retrieval [Tris EDTA, $\mathrm{pH}$ 9, in a microwave $(850 \mathrm{~W})$ for $10 \mathrm{~min}]$, followed by processing with the primary polyclonal anti-PCNA antibody (Ab 2496; Abcam, Cambridge, UK) first and then with the secondary antibody (Alexa 555 anti-rabbit; Invitrogen, OR, USA) as previously described (10). All sections were observed at x400 magnification by confocal microscopy (Leica TCS SP2 confocal laser scanning microscope). The percentage of PCNA-positive cells over the total number of counted cells, i.e., the PCNA labeling index (PCNA$\mathrm{LI}$ ), was used to quantify epithelial cell proliferation.

Terminal deoxynucleotidyl transferase-mediated deoxyuridine triphosphate nick end labeling (TUNEL) assay. Apoptotic cells were detected by TUNEL method, according to the manufacturer's instructions (In Situ Cell Death Detection kit; Roche) in 10 randomly selected fields, as previously described (12).

Western blotting. ER $\alpha$, ER $\beta$, PES1, Shh, Gli1 and $\beta$-actin protein expression levels were evaluated by western blot analysis in distal intestinal specimens. Briefly, $50 \mu \mathrm{g}$ of aliquots of total protein were separated on $4-12 \%$ pre-cast polyacrylamide gels (Invitrogen, Life Technologies) and transferred onto a PVDF membrane with Trans-Blot Turbo (both from Bio-Rad Laboratories, Milan, Italy). The primary antibodies (anti-ER $\alpha$, -ER $\beta$, -PES1, -Shh, -Gli1 and - $\beta$-actin; Santa Cruz Biotechnology, Santa Cruz, CA, USA) were diluted 1:500 in blocking buffer. After overnight incubation, the membranes were further incubated with a horseradish peroxidaseconjugated secondary antibody (Bio-Rad Laboratories). The proteins were detected by chemiluminescence (ECL; Thermo Scientific, Rockford, IL, USA) and densitometric analysis of each protein-related signal was obtained using the Molecular Imager Chemidoc ${ }^{\mathrm{TM}}$ (Bio-Rad Laboratories) and normalized against $\beta$-actin expression.

Lipogenic gene expression analysis and apoptotic death assay. To study the effects of the diets on gene expression of lipogenic enzymes and on apoptosis in the intestinal distal tract from treated mice, the mRNA levels of FAS and $H M G C O A R$ genes, as well as the levels of $\mathrm{Bax}$ and $\mathrm{Bcl}$-2, were assessed by real-time PCR (RT-PCR) as previously described (10). The reactions were obtained using Master Mix with SYBR Green 
Table I. Sequences of the amplification primers.

\begin{tabular}{|c|c|}
\hline Gene & Primers \\
\hline FAS & $\begin{array}{l}\text { Sense: } \\
\text { 5'-GATCCTGGAACGAGAACACGA-3' } \\
\text { Antisense:5'-GAGACGTGTCACTCCTGGACTTG-3 }\end{array}$ \\
\hline HMGCoAR & $\begin{array}{l}\text { Sense: } \\
\text { 5'-GCTTGAGCATCCTGACATAC-3' } \\
\text { Antisense: 5'-GAACCATAGTTCCCACGTCT-3' }\end{array}$ \\
\hline Bax & $\begin{array}{l}\text { Sense: } \\
\text { Antisense: 5'-GCAGGATGCGTCCACCAAGAA-3' } \\
\text { AnCGGAGGAAGTCCAAT-3' }\end{array}$ \\
\hline $\mathrm{Bcl}-2$ & $\begin{array}{lr}\text { Sense: } & \text { 5'-GTGGAGGAGCTCTTCAGGGA-3' } \\
\text { Antisense: } & \text { 5'-AGGCACCCAGGGTGATGCAA-3' }\end{array}$ \\
\hline$\beta$-actin & $\begin{array}{l}\text { Sense: } \\
\text { 5'-GCCTCTGGTCGTACCACTGGC-3' } \\
\text { Antisense: 5'-AGGGAGGAAGAGGATGCGGCA-3' }\end{array}$ \\
\hline
\end{tabular}

(iQ SYBR Green Supermix; Bio-Rad Laboratories) and sense and antisense primers for the target genes and the $\beta$-actin gene (Table I). Real-time PCR was carried out in a CFX96 Real-Time PCR Detection system (Bio-Rad Laboratories, Inc.) using the following protocol: 45 cycles at $95^{\circ} \mathrm{C}$ for $3 \mathrm{~min}, 95^{\circ} \mathrm{C}$ for $10 \mathrm{sec}, 55^{\circ} \mathrm{C}$ for $30 \mathrm{sec}$ followed by a melting curve step at $65-95^{\circ} \mathrm{C}$ at a heating rate of $0.5^{\circ} \mathrm{C}$ per cycle for 80 cycles. The PCR products were quantified by external calibration curves, one for each tested gene, obtained with serial dilutions of known copy numbers of molecules $\left(10^{2}-10^{7}\right.$ molecules). All expression data were normalized by dividing the target amount by the amount of $\beta$-actin used as internal control for each sample. The specificity of the PCR products was confirmed by gel electrophoresis.

Microsomal HMGCoAR activity and FAS activity assay. Microsomal HMGCoAR and FAS activities were determined on frozen distal intestinal samples, as previously described (10) and expressed as picomoles (pmol) of ${ }^{14} \mathrm{C}$ mevalonate $/ \mathrm{min} / \mathrm{mg}$ of microsomal proteins and picomoles (pmol) of incorporated $2-{ }^{14} \mathrm{C}$-malonyl-CoA $/ \mathrm{min} / \mathrm{mg}$ of total proteins, respectively.

Statistical analysis. The significance of the differences among experimental groups was evaluated by one-way analysis of variance (ANOVA) and Tukey's multiple comparison test. t-test for paired data was used to compare polyp and 'normal' mucosa parameters in the same group of animals. Differences were considered significant at a $5 \%$ probability level.

\section{Results}

Dietary treatment and gross anatomy evaluations. After 10 weeks of dietary treatment, no statistically significant difference in food consumption and body weight was found among the three groups of mice (data not shown). Gross anatomy evaluations demonstrated no significant variation in the numbers of polyps among the three groups of mice (Fig. 1A), whereas polyp volume was significantly reduced in the LOVA group (Fig. 1B, p=0.002, Tukey's multiple comparison test), but not in the OR group as compared to the ST group.

Histological studies. Notably, $40 \%$ of the mice treated with orlistat showed ulcerated polyps and widespread red pete-
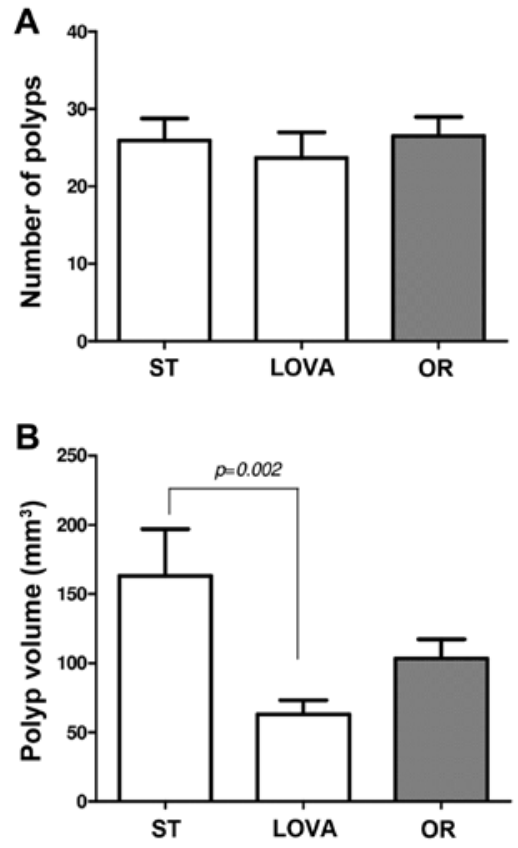

Figure 1. (A) Polyp number and (B) volume as determined in the whole intestinal tract from $A p c^{M i n /+}$ mice. ST, standard diet; LOVA, lovastatinsupplemented diet; OR, orlistat-supplemented diet. Data are expressed as mean \pm SE. $p<0.05$ indicates a statistically significant difference (one-way analysis of variance and Tukey's multiple comparison test).

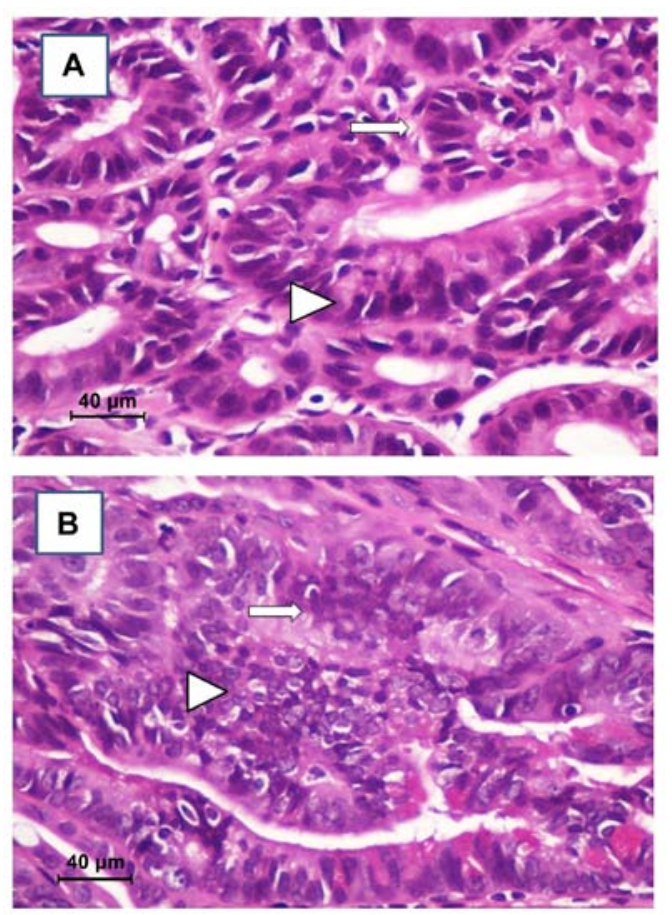

Figure 2. Histological characteristic of intestinal polyps with (A) severe dysplasia and (B) cancerous foci. (A) Glandular structure is mostly conserved (presence of glandular lumens); areas without mucine-secreting cells (arrow); epithelial cell hyperplasia with nuclear hypercromasia and mitoses (arrowhead). (B) Glandular structure is barely recognizable; widespread disappearance of mucine-secreting cells; marked cell proliferation with cellular atypia and polymorphism (arrow) and cell death (arrowhead).

chiae. Upon histological observation, while polyps in the sST and LOVA groups showed only moderate-severe grade 


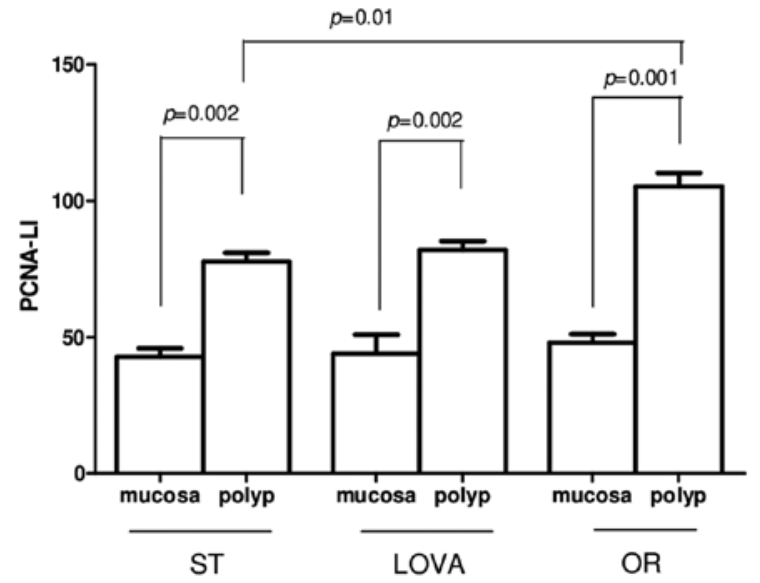

Figure 3. Cell proliferation expressed as PCNA-LI in 'normal' intestinal mucosa and polyps. ST, standard diet; LOVA, lovastatin-supplemented diet; OR, orlistat-supplemented diet. Data are expressed as mean \pm SE. $p<0.05$ indicates statistically significant difference (paired T-test or one-way analysis of variance and Tukey's multiple comparison test, where appropriate).
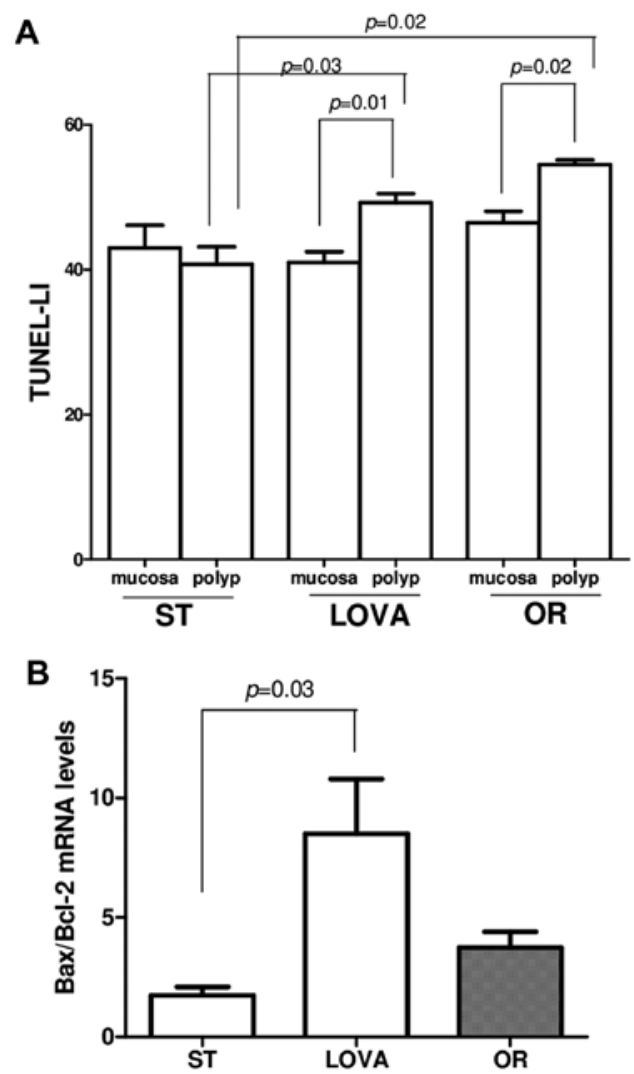

Figure 4. Cell apoptosis expressed as (A) TUNEL-LI in 'normal' intestinal mucosa and polyps and as (B) the ratio of Bax/Bcl-2 mRNA levels. ST, standard diet; LOVA, lovastatin-supplemented diet; OR, orlistat-supplemented diet. Data are expressed as mean \pm SE. $\mathrm{p}<0.05$ shows statistically significant difference (paired T-test or one-way analysis of variance and Tukey's multiple comparison test, where appropriate).

dysplasia (Fig. 2A), notable, in the OR group we found the presence of cancerous foci in the ulcerated areas (Fig. 2B).

Intestinal epithelial cell proliferation. Cell proliferation, assessed by PCNA immunohistochemical assay, was similar in
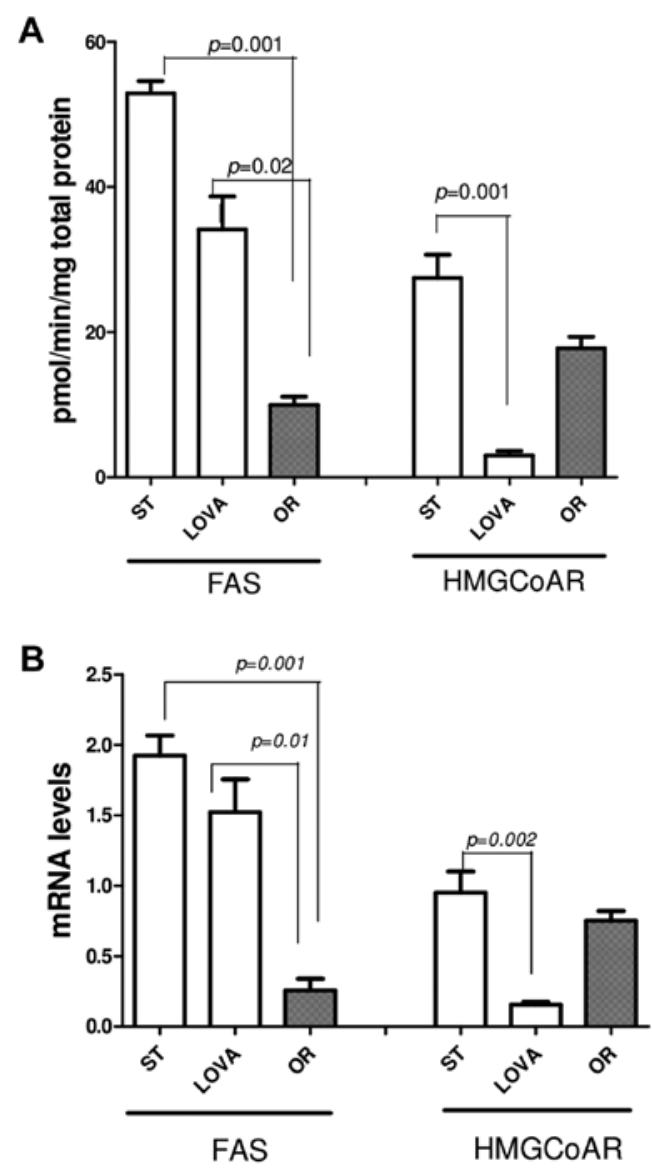

Figure 5. (A) FAS and HMGCoAR enzymatic activity and (B) mRNA levels in the polyp tissues from the $\mathrm{Apc}^{\mathrm{Min} /+}$ mouse treatment groups. ST, standard diet; LOVA, lovastatin-supplemented diet; OR, orlistat-supplemented diet. Data are expressed as mean \pm SE. $\mathrm{p}<0.05$ indicates a statistically significant difference (one-way analysis of variance and Tukey's multiple comparison test).

the 'healthy' mucosa of the three groups but was significantly increased in the polyp tissues as compared to that noted in the 'healthy' mucosa (Fig. 3, p=0.002, p=0.002 and p=0.001, paired t-test in ST, LOVA and OR groups, respectively). In particular, a statistically significant increase in cell proliferation was observed in the polyp tissues of the orlistat-treated mice compared with that noted in the mice fed a standard $\operatorname{diet}$ (Fig. 3, p=0.01, Tukey's multiple comparison test).

Intestinal epithelial cell apoptosis. Fig. 4 shows the apoptotic activity in the small intestine, expressed as TUNEL-LI (Fig. 4A) and as Bax/Bcl-2 mRNA levels (Fig. 4B). TUNEL-LI in the polyps was significantly higher as compared to the corresponding 'healthy' adjacent mucosa in the LOVA and OR groups (Fig. 4A, p=0.01, p=0.02, paired t-test, respectively) but not in the ST group. The increase in TUNEL-LI in the LOVA and OR mouse polyps was also significantly higher as compared to the ST mouse polyps ( $\mathrm{p}=0.03, \mathrm{p}=0.02$, Tukey's multiple comparison test, respectively). To confirm the results obtained by TUNEL, Bax and $\mathrm{Bcl} 2$ gene expression were evaluated demonstrating an increased $\mathrm{Bax} / \mathrm{Bcl}-2$ ratio in both the LOVA and OR mice, that reached statistical significance only in those animals receiving the diet supplemented with lovastatin (Fig. 4B, p=0.03, Tukey's multiple comparison test). 
A
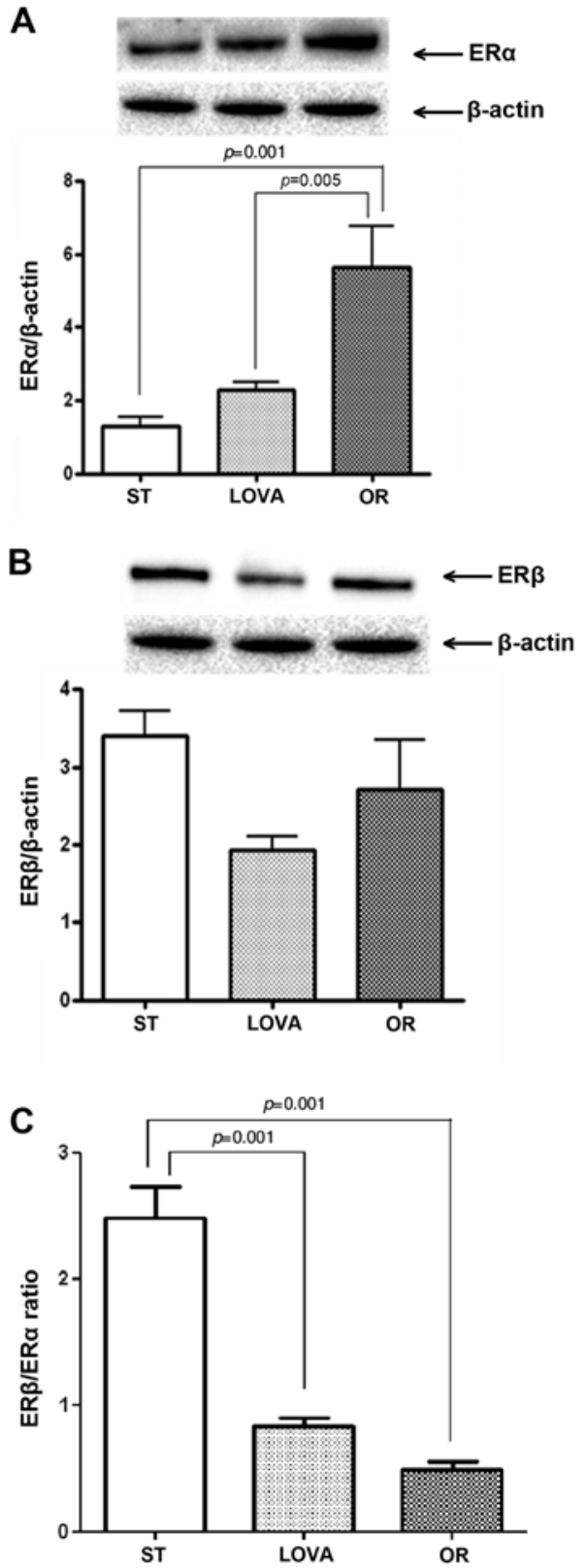

Figure 6. Western blot analysis of ER levels in the polyp tissues from the $\mathrm{Apc}^{\mathrm{Min} /+}$ mice treatment groups. Levels of (A) $\mathrm{ER} \alpha$ and (B) ER $\beta$ expression both normalized to $\beta$-actin. (C) ER $\beta / E R \alpha$ ratios. ST, standard diet; LOVA, lovastatin-supplemented diet; OR, orlistat-supplemented diet. Data are expressed as mean \pm SE. $p<0.05$ indicates a statistically significant difference (one-way analysis of variance and Tukey's multiple comparison test).

Lipogenic enzyme activity/gene expression. As expected, in the OR group, FAS activity and gene expression were significantly decreased as compared to the ST group (Fig. 5A, $\mathrm{p}=0.001$ and $5 \mathrm{~B}, \mathrm{p}=0.001$, Tukey's multiple comparison test, respectively). A similar result was found when FAS activity and gene expression in the OR group were compared to these parameters in the LOVA group (Fig. 5A, $\mathrm{p}=0.02$ and 5B, $\mathrm{p}=0.01$, Tukey's multiple comparison test, respectively). Similarly, lovastatin significantly inhibited its target HMGCoAR, demonstrating a significant reduction in both enzyme activity and mRNA as compared to ST (Fig. 5A, p=0.001 and 5B, p=0.002, Tukey's multiple comparison test, respectively).
A
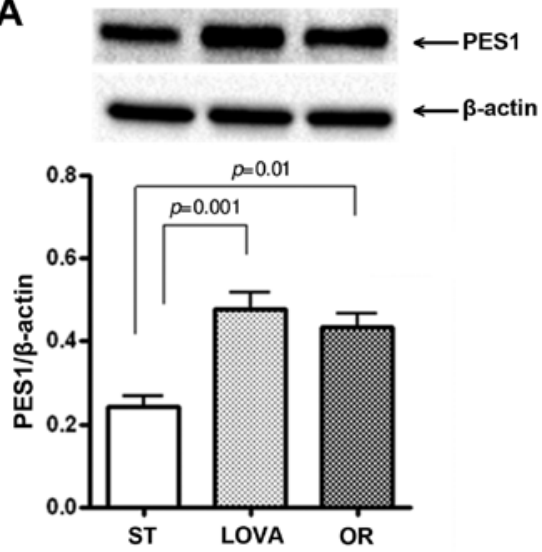

B
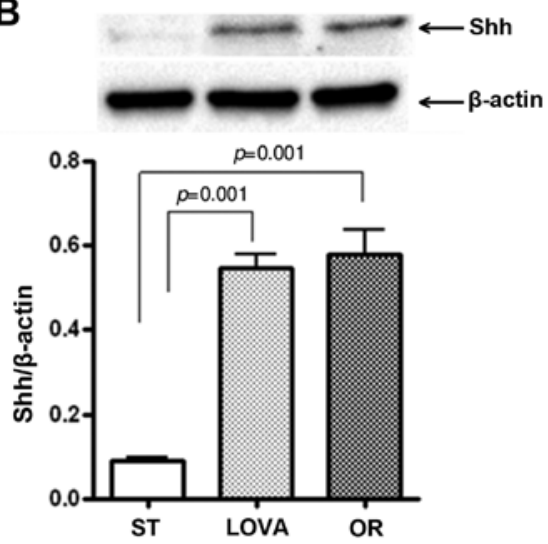

C
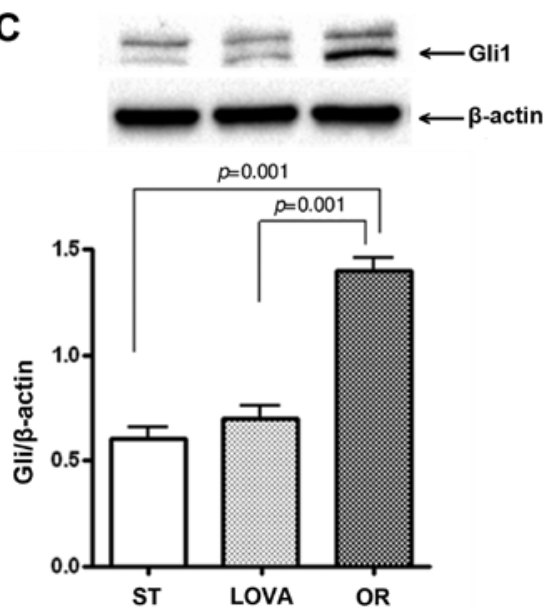

Figure 7. Western blot analysis of (A) PES1, (B) Shh and (C) Gli1 protein expression normalized to $\beta$-actin in the intestinal tract from $\mathrm{Apc}^{\mathrm{Min} /+}$ mice. ST, standard diet; LOVA, lovastatin-supplemented diet; OR, orlistat-supplemented diet. Data are expressed as mean \pm SE. $p<0.05$ indicates a statistically significant difference (one-way analysis of variance and Tukey's multiple comparison test).

ER $\alpha, P E S 1$, Shh and Glil protein expression. Fig. 6A shows a striking increase in $E R \alpha$ protein expression in the OR group as compared to that noted in the ST and LOVA groups ( $\mathrm{p}=0.001$ and $\mathrm{p}=0.005$, Tukey's multiple comparison test, respectively). Moreover, in both treatment groups, this increase was associated with a reduction in ER $\beta$ expression, that did not reached statistical significance as compared to the ST group (Fig. 6B). Consequently, in the LOVA and OR groups, the ER $\beta / E R \alpha$ ratio was significantly reduced as compared to that noted in 
the ST group (Fig. 6C, p=0.001 and p=0.001, Tukey's multiple comparison test, respectively).

Fig. 7A shows the protein levels of PES1 in the mouse treatment groups. PES1 expression was significantly increased both in the LOVA and OR groups as compared to that in the ST group ( $\mathrm{p}=0.001$ and $\mathrm{p}=0.01$, Tukey's multiple comparison test, respectively). Similarly, a statistically significant increase in Shh protein levels was observed in both treatment groups as compared to the mice fed the ST diet (Fig. 7B, p=0.001 and $\mathrm{p}=0.001$, Tukey's multiple comparison test, respectively). In contrast, the level of Gli1 protein was significantly increased only in the OR group as compared to the level in the ST and LOVA groups (Fig. $7 \mathrm{C}, \mathrm{p}=0.001$ and $\mathrm{p}=0.001$, Tukey's multiple comparison test, respectively).

\section{Discussion}

The aim of the present study was to evaluate the effects of orlistat or lovastatin on polyp formation in $\mathrm{Apc}^{\mathrm{Min} /+}$ mice, in order to confirm the same findings previously obtained with natural compounds, such as olive oil and $\omega$-3-PUFAs (10).

The use of orlistat and lovastatin significantly reduced FAS and HMGCoAR enzymatic activities and gene expression in the mouse colonic mucosa, but did not affect the number of intestinal polyps, while there was a statistically significant reduction in polyp volume only in the LOVA group. This result could be partially related to the fact that in mice receiving orlistat, the significant increase in cell proliferation in the polyp tissue was not balanced by an increase in apoptosis as observed in the LOVA group. Moreover, in the OR group, we observed the development of cancerous foci.

Moreover, lipogenic enzyme inhibition was not associated with an increase in the $\mathrm{ER} \beta / \mathrm{ER} \alpha$ ratio as observed in our previous study using olive oil and $\omega$-3-PUFAs (10). In contrast, the treatment with orlistat and lovastatin induced a modest decrease in ER $\beta$ and a significant overexpression of $\mathrm{ER} \alpha$, leading to a significant reduction in the $\mathrm{ER} \beta / \mathrm{ER} \alpha$ ratio, more evident in the OR group.

In order to clarify the involvement of ER $\alpha$ and its possible mechanism(s) of action in polyp development, we found that, in the OR group, the increased ER $\alpha$ expression was associated with a statistically significant increase in PES1, Shh and Gli1 protein levels.

PES1 has been demonstrated to increase the transcriptional activity of $E R \alpha$ and to decrease that of $E R \beta$ in breast cancer, resulting in an increased expression of estrogenresponsive genes, known to promote cell proliferation and survival (25). Since there are similarities in the carcinogenesis pathways for breast and colorectal carcinoma $(26,27)$, this study suggests an involvement of PES1 in the mechanisms regulating estrogen receptor expression in intestinal polyps of $\mathrm{Apc}^{\mathrm{Min} /+}$ mice.

An oncogenic role of the Hh pathway in promoting the proliferation of colon cancer tissue has also been widely described $(18-20,28)$. Moreover, it has been demonstrated that overexpression of the Hh pathway in intestinal adenoma increases both the incidence and the size of the adenomas in $\mathrm{Apc}^{\mathrm{Min} /+}$ mice (28). Our recent study demonstrated that Shh protein expression also plays a role in molecular mechanisms of polyp reversion in $\mathrm{Apc}^{\mathrm{Min} /+}$ mice (29).
In the present study, in the mice treated with lovastatin, the Gli1 protein remained unmodified and only the PES1 and Shh proteins were overexpressed. The fact that in the LOVA group we did not find a correlation between the increased expression of Shh and Gli1 was not surprising since it is already known that Glil expression may not be necessarily associated with an upregulation of Shh expression (18).

Our present data clearly demonstrated that lovastatin, but not orlistat, reduced intestinal polyp volume in the $\mathrm{Apc}^{\mathrm{Min} /+}$ mouse model, probably due to an increase in ER $\alpha$ expression, known to be a positive modulator of cell proliferation.

Our findings are in agreement with research demonstrating that orlistat treatment is associated with a significant increase in the number of colonic aberrant crypt foci as well as the induction of colonic cell proliferation and severe crypt alterations (30). In this scenario, the apparent discordance with other data in the literature demonstrating the anti-proliferative effect of orlistat could be related to the different experimental models used (6-8).

Finally, from our present data, we suggest that, in addition to the inhibition of FAS enzyme activity and gene expression, other intestinal tissue molecular changes occur during orlistat treatment in $\mathrm{Apc}^{\mathrm{Min} /+}$ mice. Therefore, further research is warranted to elucidate the negative or beneficial side effects of this drug.

\section{References}

1. Shibata MA, Kavanaugh C, Shibata E, Abe H, Nguyen P, Otsuki Y, Trepel JB and Green JE: Comparative effects of lovastatin on mammary and prostate oncogenesis in transgenic mouse models. Carcinogenesis 24: 453-459, 2003.

2. Kuhajda FP, Pizer ES, Li JN, Mani NS, Frehywot GL and Townsend CA: Synthesis and antitumor activity of an inhibitor of fatty acid synthase. Proc Natl Acad Sci USA 97: 3450-3454, 2000.

3. Orita H, Coulter J, Tully E, Kuhajda FP and Gabrielson E: Inhibiting fatty acid synthase for chemoprevention of chemically induced lung tumors. Clin Cancer Res 14: 2458-2464, 2008.

4. Pizer ES, Chrest FJ, DiGiuseppe JA and Han WF: Pharmacological inhibitors of mammalian fatty acid synthase suppress DNA replication and induce apoptosis in tumor cell lines. Cancer Res 58: 4611-4615, 1998.

5. Wong WW, Dimitroulakos J, Minden MD and Penn LZ: HMG-CoA reductase inhibitors and the malignant cell: The statin family of drugs as triggers of tumor-specific apoptosis. Leukemia 16: 508-519, 2002.

6. Kridel SJ, Axelrod F, Rozenkrantz N and Smith JW: Orlistat is a novel inhibitor of fatty acid synthase with antitumor activity. Cancer Res 64: 2070-2075, 2004.

7. Chuang HY, Chang YF and Hwang JJ: Antitumor effect of orlistat, a fatty acid synthase inhibitor, is via activation of caspase-3 on human colorectal carcinoma-bearing animal. Biomed Pharmacother 65: 286-292, 2011.

8. Carvalho MA, Zecchin KG, Seguin F, Bastos DC, Agostini M, Rangel AL, Veiga SS, Raposo HF, Oliveira HC, Loda M, et al: Fatty acid synthase inhibition with Orlistat promotes apoptosis and reduces cell growth and lymph node metastasis in a mouse melanoma model. Int J Cancer 123: 2557-2565, 2008.

9. Notarnicola M, Messa C, Refolo MG, Tutino V, Miccolis A and Caruso MG: Synergic effect of eicosapentaenoic acid and lovastatin on gene expression of HMGCoA reductase and LDL receptor in cultured HepG2 cells. Lipids Health Dis 9: 135, 2010.

10. Barone M, Notarnicola M, Caruso MG, Scavo MP, Viggiani MT, Tutino V, Polimeno L, Pesetti B, Di Leo A and Francavilla A: Olive oil and omega-3 polyunsaturated fatty acids suppress intestinal polyp growth by modulating the apoptotic process in $\mathrm{Apc}^{\mathrm{Min} /+}$ mice. Carcinogenesis 35: 1613-1619, 2014. 
11. Barone M, Tanzi S, Lofano K, Scavo MP, Guido R, Demarinis $+\mathrm{L}$, Principi MB, Bucci A and Di Leo A: Estrogens, phytoestrogens and colorectal neoproliferative lesions. Genes Nutr 3: 7-13, 2008.

12. Barone M, Scavo MP, Papagni S, Piscitelli D, Guido R, Di Lena M, Comelli MC and Di Leo A: ER $\beta$ expression in normal, adenomatous and carcinomatous tissues of patients with familial adenomatous polyposis. Scand J Gastroenterol 45: $1320-1328,2010$

13. Konstantinopoulos PA, Kominea A, Vandoros G, Sykiotis GP, Andricopoulos P, Varakis I, Sotiropoulou-Bonikou G and Papavassiliou AG: Oestrogen receptor beta (ERbeta) is abundantly expressed in normal colonic mucosa, but declines in colon adenocarcinoma paralleling the tumour's dedifferentiation. Eur J Cancer 39: 1251-1258, 2003.

14. Rudolph A, Toth C, Hoffmeister M, Roth W, Herpel E, Jansen L, Marx A, Brenner $\mathrm{H}$ and Chang-Claude J: Expression of oestrogen receptor $\beta$ and prognosis of colorectal cancer. Br J Cancer 107: 831-839, 2012.

15. Di Leo A, Barone M, Maiorano E, Tanzi S, Piscitelli D, Marangi S, Lofano K, Ierardi E, Principi M and Francavilla A: ER-beta expression in large bowel adenomas: Implications in colon carcinogenesis. Dig Liver Dis 40: 260-266, 2008.

16. Weihua Z, Andersson S, Cheng G, Simpson ER, Warner M and Gustafsson JA: Update on estrogen signaling. FEBS Lett 546: $17-24,2003$.

17. Thomas $C$ and Gustafsson JA: The different roles of ER subtypes in cancer biology and therapy. Nat Rev Cancer 11: 597-608, 2011.

18. Gulino A, Ferretti E and De Smaele E: Hedgehog signalling in colon cancer and stem cells. EMBO Mol Med 1: 300-302, 2009.

19. Wang H, Li YY, Wu YY and Nie YQ: Expression and clinical significance of hedgehog signaling pathway related components in colorectal cancer. Asian Pac J Cancer Prev 13: 2319-2324, 2012.

20. Kameda C, Nakamura M, Tanaka H, Yamasaki A, Kubo M, Tanaka M, Onishi $\mathrm{H}$ and Katano M: Oestrogen receptor-alpha contributes to the regulation of the hedgehog signalling pathway in ERalpha-positive gastric cancer. Br J Cancer 102: 738-747, 2010.
21. Bian YH, Huang SH, Yang L, Ma XL, Xie JW and Zhang HW: Sonic hedgehog-Gli1 pathway in colorectal adenocarcinomas. World J Gastroenterol 13: 1659-1665, 2007.

22. Kinoshita Y, Jarell AD, Flaman JM, Foltz G, Schuster J, Sopher BL, Irvin DK, Kanning K, Kornblum HI, Nelson PS, et al: Pescadillo, a novel cell cycle regulatory protein abnormally expressed in malignant cells. J Biol Chem 276: 6656-6665, 2001.

23. Maiorana A, Tu X, Cheng G and Baserga R: Role of pescadillo in the transformation and immortalization of mammalian cells Oncogene 23: 7116-7124, 2004.

24. Xie W, Feng Q, Su Y, Dong B, Wu J, Meng L, Qu L and Shou C: Transcriptional regulation of PES1 expression by c-Jun in colon cancer. PLoS One 7: e42253, 2012.

25. Cheng L, Li J, Han Y, Lin J, Niu C, Zhou Z, Yuan B, Huang K, Li J, Jiang K, et al: PES1 promotes breast cancer by differentially regulating $E R \alpha$ and $E R \beta$. J Clin Invest 122: 2857-2870, 2012.

26. Dey P, Barros RP, Warner M, Ström A and Gustafsson JA: Insight into the mechanisms of action of estrogen receptor $\beta$ in the breast, prostate, colon, and CNS. J Mol Endocrinol 51: T61-T74, 2013.

27. Papapolychroniadis C, Kaimakis D, Giannoulis K, Papadopoulos V, Zatagias A, Halvatzoulis O, Kostopoulos J, Kokkonis G, Giala M and Harlaftis N: Metachronous breast carcinoma (second malignancy), following 'cure' from colorectal carcinoma. Tech Coloproctol 8 (Suppl 1): s129-s131, 2004

28. Büller NV, Rosekrans SL, Metcalfe C, Heijmans J, van Dop WA, Fessler E, Jansen M, Ahn C, Vermeulen JL, Westendorp BF, et al: Stromal Indian hedgehog signaling is required for intestinal adenoma formation in mice. Gastroenterology 148: 170-180.e6, 2015.

29. Notarnicola M, Tutino V, Caruso MG and Francavilla A: n-3 polyunsaturated fatty acids reverse the development of polyps in $\mathrm{Apc}^{\mathrm{Min} /+}$ transgenic mice. Oncol Rep 35: 504-510, 2016.

30. Garcia SB, Barros LT, Turatti A, Martinello F, Modiano P, Ribeiro-Silva A, Vespúcio MV and Uyemura SA: The anti-obesity agent Orlistat is associated to increase in colonic preneoplastic markers in rats treated with a chemical carcinogen. Cancer Lett 240: 221-224, 2006. 